\title{
KECERNAAN PAKAN KELINCI LOKAL (Lepus nigricollis) YANG DIBERI PAKAN MULTI NUTRIENT BLOCK BERBASIS RUMPUT LAPANGAN
}

\author{
PUGER, A.W., I M. NURIYASA, E.PUSPANY DAN I M. MASTIKA \\ Fakultas Peternakan Universitas Udayana \\ puger.anton@gmail.com
}

\begin{abstract}
ABSTRAK
Peningkatan produktivitas ternak kelinci dapat diukur dari kecernaan pakan yang diberikan dan dapat dilakukan dengan memberikan suplementasi Mineral Nutrient Block (MNB). Penelitian dilaksanakan dengan menggunakan Rangcangan Acak Kelompok (RAK) dengan lima kali ulangan. Perlakuan yang diberikan adalah Ro: pakan kontrol (rumput lapangan) dengan kandungan energi termetabolis $1830 \mathrm{kkal} / \mathrm{kg}$ dan CP:9,1\%, R1: ransum kontrol yang disuplementasi MNB 5 g/ekor/hari, R2: ransum kontrol yang disuplementasi MNB 10 g/ekor/hari, R3: ransum kontrol yang disuplementasi MNB $15 \mathrm{~g} /$ ekor/hari. Rumput lapangan diberikan secara ad libitum dalam bentuk segar dan dipotong-potong dengan panjang $5 \mathrm{~cm}$. Hasil penelitian menunjukkan bahwa nilai cerna bahan kering, nilai cerna energi dan nilai cerna protein tertinggi pada R3 yaitu masing-masing 59,22\%, 68,88\% dan 43,72\%. Dari hasil penelitian ini dapat disimpulkan bahwa pemberian Multi Nutrient Block sebanyak 15\% memberikan kecernaan tertinggi pada kecernaan bahan kering, energi dan protein pakan.
\end{abstract}

Kata kunci : Kelinci lokal, MNB, rumput lapangan, produktivitas

\section{FEED DIGESTIBILITY OF RABBITS FED WITH MULTI-NUTRIENT BLOCK BASED GRASS FIELD}

\begin{abstract}
Increased productivity of rabbits can be measured from the digestibility of feed offered and can be done by providing Mineral Nutrient Block (MNB) supplementation. The experiment was conducted using Completely Randomized Block Design (CRBD) with five replications. The treatments were Ro: control diet (grass field) with metabolic energy content $1830 \mathrm{kcal} / \mathrm{kg}$ and CP: 9.1\%, R1: control diet supplemented MNB $5 \mathrm{~g} / \mathrm{head} /$ day, R2: control diet supplemented MNB $10 \mathrm{~g} / \mathrm{head} /$ day, R3: control diet supplemented MNB $15 \mathrm{~g} / \mathrm{head} / \mathrm{day}$. Grass field provided ad libitum in the form of fresh and cut into $5 \mathrm{~cm}$ along. The results showed that the highest digestibility value of dry matter, energy and protein in $\mathrm{R} 3$, respectively $59.22 \%, 68.88 \%$ and $43.72 \%$. From these results it can be concluded that the supplementation of Multi Nutrient Block as many as 15\% give the highest digestibility of dry matter, energy and protein of feed.
\end{abstract}

Keywords: Local Rabbits, MNB, grass field, productivity

\section{PENDAHULUAN}

Pengembangan budidaya kelinci di masyarakat sudah lama dilakukan, namun jumlah peternak dan populasinya masih sangat rendah. Dilihat dari potensi, kelinci sangat potensial dikembangkan sebagai penghasil daging berkualitas dengan waktu lebih cepat dibandingkan dengan ruminansia besar (sapi). Salah satu kelemahan peternak kelinci sampai saat ini adalah pengetahuan tentang kualitas pakan sangat rendah terutama pemahaman asupan protein, energi dan mineral.

Kelinci memerlukan nutrien berupa: karbohidrat, protein, lemak, mineral, vitamin dan air (de Blass dan Wiseman, 1998). Menurut McNitt et al. (1996) kebutuhan energi pada ternak kelinci dapat pula dinyatakan dalam DE disamping ada pula beberapa peneliti memakai dasar perhitungan ME. Parigi Bini dan Xiccato (1998) menyatakan bahwa dasar perhitungan kebutuhan energi ternak kelinci dalam bentuk ME dapat dicari dengan mengalikan DE dengan bilangan konstanta (k). Beberapa peneliti mendapatkan nilai $\mathrm{k}$ yang sama yaitu 0,95 diantaranya : de Blas et al. (1985); Parigi Bini dan Xiccato (1986); Partridge et al. (1989); Xiccato et al. (1995).

Menurut Praga (1998) hanya sebagian kecil protein 
dapat dicerna dalam sekum dan kolon karena sebagian besar sudah tercerna dalam usus halus. Amonia adalah hasil akhir metabolisme $\mathrm{N}$ dan merupakan sumber utama sintesis mikroorganisme dalam sekum dan kolon. Jumlah amonia yang normal dalam sekum berkisar 4,5 - $6 \mathrm{mmol} /$ liter. Dong et al. (2010) mendapatkan bahwa ternak kelinci persilangan yang diberi ransum dasar para grass dan water spinach (ipomoea aquatica) yang disuplementasi konsentrat sebagai sumber protein sebanyak $37 \mathrm{~g} /$ ekor/hari menghasilkan jumlah kelahiran, jumlah sapih dan berat sapih lebih tinggi daripada $34 \mathrm{~g} /$ ekor/hari, $31 \mathrm{~g} /$ ekor/hari dan $28 \mathrm{~g} /$ ekor/ hari.

Suttle (2010) menyatakan bahwa mineral merupakan nutrien yang diperlukan dalam jumlah sedikit namun mempunyai peranan penting dalam metabolism ternak. Mineral berperanan dalam hal: (1) sebagai pembentukan organ tubuh, (2) fungsi fisiologis, (3) fungsi katalisator enzim dan (4) berperanan dalam replikasi dan pemecahan sel. Di lapangan, peternak memberikan ransum yang sama pada semua status fisiologi ternak. Kuantitas dan kualitas ransum tidak pernah menjadi pertimbangan oleh peternak dan diberikan seadanya. Pemeliharaan kelinci seperti ini sering menjadi keluhan oleh peternak karena banyak anak kelinci mati atau induk bersifat kanibalisme. Xiccato et al. (1999) menyatakan keseimbangan nutrient dalam ransum sangat menentukan produktivitas ternak kelinci. Menurut de Blass dan Wiseman (1998) protein, karbohidrat, lemak, mineral, vitamin dan air merupakan nutrien yang sangat diperlukan oleh ternak kelinci.

Salah satu usaha untuk meningkatkan performans yang dapat dilihat dari penampilan kecernaan pakan dengan memberikan suplementasi Mineral Nutrient Block (MNB) pada ransum yang berbahan dasar rumput lapangan.

\section{MATERI DAN METODE}

Kelinci. Penelitian dilakukan dengan menggunakan kelinci jantan sebanyak 40 ekor (calon pejantan) umur 5 minggu

Tempat dan Lama Penelitian. Penelitian lapangan selama 12 minggu dan dilaksanakan di Desa Dajan Peken, Kecamatan Tabanan, Kabupaten Tabanan (50m dpl). Analisis pakan dilaksanakan di Laboratorium $\mathrm{Nu}-$ trisi Fakultas Peternakan, Universitas Udayana, Denpasar dan Laboratorium Ilmu dan Teknologi Pakan, Institut Pertanian, Bogor.

Kandang dan Ternak. Penelitian menggunakan 40 petak kandang dengan ukuran masing-masing panjang $70 \mathrm{Cm}$, lebar $50 \mathrm{Cm}$ dan tinggi $45 \mathrm{Cm}$ (Sceire, 1999). Ketinggian petak kandang diukur dari lantai bangunan kandang adalah $70 \mathrm{Cm}$. Masing-masing petak kandang dilengkapi dengan tempat makanan dan tempat air minum yang terbuat dari tempurung kelapa.

Pakan. Multi Nutrient Block (MNB) dibuat dari bahan-bahan seperti tepung polar, ampas tahu, molasses, minyak kelapa, garam, kalsium hidrofosfat dan semen putih. Kandungan MNB dibuat memenuhi kebutuhan energi (ME) $2400 \mathrm{kkal} / \mathrm{kg}$ dan protein $16 \%$

Metode Penelitian. Percobaan lapangan dilaksanakan dengan menggunakan Rangcangan Acak Kelompok (RAK) dengan lima kali ulangan. Ransum kontrol adalah rumput lapangan (Ro), ransum kontrol yang disuplementasi MNB $5 \mathrm{~g} /$ ekor/h (R1), ransum kontrol yang disuplementasi MNB $10 \mathrm{~g} / \mathrm{ekor} / \mathrm{h}$ (R2), ransum kontrol yang disuplementasi MNB $15 \mathrm{~g} / \mathrm{ekor} / \mathrm{h}$ (R3). Nutrien dicetak dalam bentuk balok dengan ukuran panjang $5 \mathrm{~cm}$, lebar $3 \mathrm{~cm}$ dan tinggi $3 \mathrm{~cm}$. Komposisi dan kandungan nutrien NMB disajikan pada Tabel 1.

Tabel 1. Multi Nutrient Block (MNB)

\begin{tabular}{|c|c|c|c|c|c|c|c|}
\hline Bahan & $\begin{array}{c}\text { Persen- } \\
\text { tase }\end{array}$ & $\begin{array}{c}\mathrm{ME} \\
\text { (Kkal/Kg) }\end{array}$ & $\begin{array}{l}\mathrm{CP} \\
(\%)\end{array}$ & $\begin{array}{l}\mathrm{Ca} \\
(\%)\end{array}$ & $\begin{array}{l}\text { Pav } \\
(\%)\end{array}$ & $\begin{array}{c}\text { Lemak } \\
\text { (\%) }\end{array}$ & CF (\%) \\
\hline Molases $\left.{ }^{*}\right)$ & 5 & 98 & & & & & \\
\hline Polar $\left.{ }^{*}\right)$ & 18 & 205,2 & 2,12 & 0,02 & 0,06 & 0.057 & 14.75 \\
\hline $\begin{array}{l}\text { Ampas Tahu } \\
\text { terfermentasi }^{* * *} \text { ) }\end{array}$ & 60 & 1698 & 14,17 & 0,32 & 0,14 & 6 & 0.6 \\
\hline semen putih & 5 & 0 & 0 & 0 & 0 & 0 & 0 \\
\hline $\begin{array}{l}\text { Kalsium Hidro } \\
\left.\text { Posfat }{ }^{* *}\right)\end{array}$ & 6.5 & 0 & 0 & 1,66 & 1,17 & 0 & 0 \\
\hline $\mathrm{NaCl}$ & 0.5 & 0 & 0 & 0 & 0 & 0 & 0 \\
\hline minyak kelapa $\left.{ }^{*}\right)$ & 5 & 430 & 0 & 0 & 0 & 0 & 0 \\
\hline Total & 100 & 2431,2 & 16,29 & 2,0 & 1,37 & 6.057 & 15.35 \\
\hline
\end{tabular}

*) Perhitungan berdasarkan Scott et al. (1982)

**) Perhitungan Yichang Shinta Foreign Trade Co., Ltd

***) Perhitungan Duldjaman (2005)

\section{Variabel yang Diukur}

Koefisien Cerna Bahan Kering Ransum. Koefisien Cerna Bahan Kering (KCBK) dihitung berdasarkan metode koleksi total (Tillman et al., 1989). KCBK dihitung dengan formulasi :

$$
\mathrm{A}-\mathrm{BA} \times 100 \%
$$

Keterangan

KCBK: Koefisien cerna bahan kering (\%), A: Konsumsi bahan kering ransum (g) dan B: Jumlah bahan kering ekskreta (g)

Kecernaan Energi. Kecernaan energi dihitung dengan menggunakan formulasi :

$$
\mathrm{A}-\mathrm{BA} \times 100 \%
$$

Keterangan:

A: Konsumsi energi kkal/hari dan B: Kandungan protein pada feses (kkal/hari).

Kecernaan Protein. Kecernaan protein dihitung dengan menggunakan formulasi :

$\mathrm{A}-\mathrm{BA} \times 100 \%$

Keterangan:

A: Konsumsi protein (g/hari) dan B: Kandungan protein pada feses (g/hari). 


\section{Analisis Data}

Data yang diproleh dianalisis dengan analisis ragam, apabila diantara perlakuan terdapat perbedaan yang nyata $(\mathrm{P}<0,05)$ maka analisis dilanjutkan dengan uji jarak berganda Duncan (Steel dan Torrie, 1980).

\section{HASIL DAN PEMBAHASAN}

Nilai cerna bahan kering ransum pada kelinci yang mendapat perlakuan $\mathrm{R}_{3}$ paling tinggi $(59,22 \%)$, seperti pada Tabel 2. Nilai cerna ransum pada kelinci yang diberi perlakuan R2 adalah o,81\% lebih rendah $(\mathrm{P}>0,05)$ daripada R3. Nilai cerna bahan kering perlakuan R1 dan Ro masing-masing 5,23\% dan 6,65\% nyata lebih rendah $(\mathrm{P}<0,05)$ dibandingkan dengan perlakuan $\mathrm{R} 3$.

Nilai cerna energy tertinggi pada kelinci yang diberikan perlakuan R3 yaitu 68,88 \%. Kelinci yang diberikan perlakuan R2 nilai cerna energy 0,92\% lebih rendah $(\mathrm{P}>0,05)$ dari R3. Kelinci yang mendapat perlakuan ransum R1 menyebabkan nilai cerna energy ransum 66,38\% dan 3,63\% nyata lebih rendah $(\mathrm{P}<0,05)$. Nilai cerna energy ransum control (Ro) adalah $66,22 \%$ dan $3,86 \%$ nyata lebih rendah $(\mathrm{P}<0,05)$ dibandingakn dengan $\mathrm{R}_{3}$.

Terdapat kecenderungan nilai cerna protein tertinggi pada $\mathrm{R} 3$ meskipun secara statistik tidak terjadi perbedaan yang nyata $(\mathrm{P}>0,05)$ pada variabel nilai cerna protein diantara perlakuan Ro, R1, R2 dan R3.

Tabel 2. Nilai Cerna Ransum pada Kelinci Mendapat Perlakuan Suplementasi dan Tanpa Suplementasi MNB

\begin{tabular}{lrrrrr}
\hline \multirow{2}{*}{ Variabel } & \multicolumn{5}{c}{ Perlakuan } \\
\cline { 2 - 6 } & \multicolumn{1}{c}{ R0 } & \multicolumn{1}{c}{ R1 } & \multicolumn{1}{c}{ R2 } & \multicolumn{1}{c}{ R3 } & SEM \\
\hline Nilai Cerna Bahan Kering (\%) & $55,28^{\mathrm{b}}$ & $56,12^{\mathrm{b}}$ & $58,74^{\mathrm{a}}$ & $59,22^{\mathrm{a}}$ & 0,18 \\
Nilai Cerna Energi (\%) & $66,22^{\mathrm{b}}$ & $66,38^{\mathrm{b}}$ & $68.24^{\mathrm{a}}$ & $68,88^{\mathrm{a}}$ & 0,26 \\
Nilai Cerna Protein (\%) & $42,66^{\mathrm{a}}$ & $42,63^{\mathrm{a}}$ & $43,37^{\mathrm{a}}$ & $43,72^{\mathrm{a}}$ & 0,48 \\
Konsumsi Energi (kkal/hr) & $175,18^{\mathrm{c}}$ & $207,96^{\mathrm{b}}$ & $222,59^{\mathrm{a}}$ & $228,51^{\mathrm{a}}$ & 1,44 \\
Energi Feses (FE) kkal/hr & $45,76^{\mathrm{b}}$ & $46,05^{\mathrm{b}}$ & $52,8^{\mathrm{a}}$ & $53,18^{\mathrm{a}}$ & 0,25 \\
Konsumsi Protein (g/hr) & $6,18^{\mathrm{c}}$ & $6,45^{\mathrm{b}}$ & $6,51^{\mathrm{b}}$ & $6,75^{\mathrm{a}}$ & 0,08 \\
Protein Feses (g/hr) & $0,36^{\mathrm{a}}$ & $0,35^{\mathrm{a}}$ & $0,34^{\mathrm{a}}$ & $0,34^{\mathrm{a}}$ & 0,005 \\
\hline
\end{tabular}

RO : Ramsum rumput lapangan tanpa suplementasi MNB

R1 : Ransum rumput lapangan dengan suplementasi MNB $5 \mathrm{~g} / \mathrm{hr}$

$\mathrm{R} 2$ : Ransum rumput lapangan dengan suplementasi MNB $10 \mathrm{~g} / \mathrm{hr}$

R3 : Ransum rumput lapangan dengan suplementasi MNB $15 \mathrm{~g} / \mathrm{hr}$

Superskrip yang sama pada baris yang sama menunjukkan perbedaan tidak nyata $(P>0,05)$ SEM: Standard Error of The Treatment Means

Kelinci yang diberikan ransum R3 kecernaan bahan kering ransum 59,22\% lebih tinggi dari perlakuan Ro, R1 dan R2 (Tabel 2). Tillman, et al. (1986) melaporkan bahwa kecernaan bahan kering ransum dipengaruhi oleh komposisi bahan penyusun ransum dan bentuk fisik ransum. Tingginya kecernaan ransum $\mathrm{R}_{3}$ disebabkan karena kecernaan energy dan protein juga tertinggi. Hal ini disebabkan juga karena konsumsi MNB meningkat sehingga mengurangi konsumsi rumput yang diketahui kecernaan molasis dan ampas tahu sebagai penyusun
MNB lebih tinggi dari rumput. Hal ini diperkuat oleh hasil penelitian Puger et al (2015) yang menyatakan penampilan kelinci yang diberikan MNB terbaik pada pemberian MNB level 15\%. Rata-rata kecernaan bahan kering kelinci jantan lokal pada penelitian ini adalah 57,34\%. Nuriyasa (2012) mendapatkan rata-rata kecernaan bahan kering kelinci jantan lokal adalah 68,52\%. Perbedaan ini disebabkan karena perbedaan bahan pakan yang dipakai untuk menyusun ransum. Hasil penelitian ini sesuai dengan penelitian Nuriyasa et al. (2013) yang menyatakan performans kelinci tertinggi pada pemberian ransum dengan protein $16 \%$ dan Energi termetabolis $2800 \mathrm{kkal} / \mathrm{kg}$ dibanding dengan energi termetabolis $2200 \mathrm{kkal} / \mathrm{kg}, 2500 \mathrm{kkal} /$ $\mathrm{kg}$ dan $3100 \mathrm{kkal} / \mathrm{kg}$. Demikian juga Puspany et al. 2015 menyatakan kelinci yang diiberi ransum dengan imbangan energy protein 147 menghasilkan performans lebih baik dari imbangan 151. Hasil penelitian yang agak berbeda dilaporkan oleh Budiari (2014), Nuriyasa et al. (2015) memberikan limbah kopi terfermentasi nilai cerna tertinggi bila disuplementasi dengan $10 \%$. Perbedaan ini disebabkan bahan penyusun berbeda, kulit kopi mempunyai rasa pahit availabilitas nutrisi lebih rendah dari aampas tahu.

Kecernaan energi pada ransum $\mathrm{R}_{3}$ adalah $68,88 \%$ paling tinggi dari perlakuan Ro,R1 dan R2 (Tabel 2). Hal ini disebabkan karena konsumsi energi yang tinggi dan energi feses yang dikeluarkan lebih sedikit (Tabel 2) sehingga kecernaan energinya tinggi. Kecernaan energi paling tinggi pada $\mathrm{R}_{3}$ juga disebabkan karena kandungan serat kasar ransum $\mathrm{R}_{3}$ paling rendah akibatnya daya cerna ransum meningkat dan energi yang dapat dicerna juga meningkat.

Tidak terjadi perbedaan terhadap variabel kecernaan protein diantara perlakuan Ro, R1, R2 dan $\mathrm{R}_{3}$, hal ini disebabkan karena konsumsi protein dan protein feses yang dihasilkan tidak berbeda antara perlakuan sehingga kecernaan protein masing-masing perlakuan adalah sama. Tidak berbedanya kecernaan protein didukung hasil penelitian Nuriyasa et al 2014 yang menyatakan suplementasi ampas tahu yng diberi ragi dan tidak tidak berpengaruh terhadap penampilan ternak.

\section{SIMPULAN}

Dari hasil penelitian dapat disimpulkan bahwa kecernaan bahan kering dan kecernaan energi kelinci yang diberi pakan dasar rumput lapangan dengan suplementasi MNB $15 \mathrm{~g} / \mathrm{hari}$ lebih baik daripada suplementasi 10 dan $5 \mathrm{~g} /$ hari, namun aras seplementasi MNB tidak berpengaruh pada kecernaan protein. 


\section{UCAPAN TERIMAKASIH}

Ucapan terima kasih disampaikan kepada Rektor Universitas Udayana melalui Lembaga Penelitian dan Pengabdian pada Masyarakat Universitas Udayana atas dana Hibah Perguruan Tinggi, atas kesempatan dan fasilitas yang diberikan.

\section{DAFTAR PUSTAKA}

Budiari, N.L.G. 2014. Pengaruh Aras Kulit Kopi Terfermentasi dalam Ransum terhadap Pertumbuhan Kelinci Lokal Jantan (Lepus Negricollis). Thesis. Program Magister Ilmu Peternakan Program Pascasarjana Universitas Udayana Denpasar

De Blass, C and J. Wiseman. 1998. The Nutrition of the Rabbit. CABI Publishinr. University of Nottingham. Nottingham. P.39-55.

Dong, T.K. N., N. Van Thu and T.R. Preston. 2010. Effect of Dietery Protein Supply on the Reproductive Performance of Crossbred Rabbits. Cantho University, Cantho City, Vietnam.

Mc.Nitt, J.I., N.M. Nephi, S.D. Lukefahr and P.R. Cheeke. 1996. Rabbit Production. Interstate Publishers, Inc.p. 78-109.

Nuriyasa I M., I. M. Mastika and G. A. M. K. Dewi. 2015. Performance of local rabbit (Lepus nigricollis) fed diets containing different level of fermented coffee pulp. African Journal of Agricultural Research. Vol. 10(52), pp. 4820-4824, 24 December, 2015

Nuriyasa, I M., I M. Mastika, I G. Mahardika, I W. Kasa, I G.Ag. I. Aryani. 2104. Energy and protein retention of local rabbit housed in different cages. Journal of Biological and Chemical Research. Vol. 31, No. 2 : $800-807$.

Nuriyasa, I.M., I.M. Mastika, A.W. Puger, E. Puspany dan I.W. Wirawan. 2013. Performanns kelinci local (Lepus nigricollis) yang diberi ransum dengan kandungan energi yang berbeda. Majalah Ilmiah Peternakan. Vol 16. No 1: 12-17
Nuriyasa, I.M., N.G.K. Roni, E. Puspani, D.P.M.A Candrawati, I.W. Wirawan, A.W. Puger. 2014. Respon fisiologi kelinci lokal yang diberi ransum menggunakan ampas tahu yang disuplementasi ragi tape pada jenis kandang berbeda. Majalah Ilmiah Peternakan. Vol. 17, No. 2: $61-65$.

Parigi Bini and R., G. Xiccato. 1998. Energy Metabolism and Requirements. In. The Nutrition of the Rabbit. Ed. C. de Blas and J.Wiseman. CABI Publishing, New York. p.103-132.

Partridge, G. G., P.H. Garthwaite, M. Findlay. 1989. Protein and Energy Retention by Growing Rabbits Offered Diets with Increasing Proportions of Fibre. Journal of Agriculture Science, Cambridge 112, $171-178$.

Praga, M.J. 1998. Protein Requirment. In. The Nutrition of the Rabbit. Ed. C. de Blas and J.Wiseman. CABI Publishing, New York. p.133-143.

Puger A.W., I M. Nuriyasa dan E. Puspany. Performans kelinci local (Lepus nigricollis) yang diberi pakan dasar rumput lapangan disuplementasi Multi Nutrient Block (MNB) dengan aras berbeda. Prosiding. Seminar Nasional Sains dan Teknologi II 2015. Kuta, 29-30 Oktober 2015. 5 hal

Puspany E., N.G.K. Ron dan I M. Nuriyasa. 2015. Performans dan indeks kelembaban suhu kelinci jantan (Lepus nigricollis) yang dipelihara dengan luas lantai kandang dan diberi ransum dengan imbangan energy dan protein berbeda. Majalah Ilmiah Peternakan. Vol. 18, No. 1: 1-4.

Schiere, J.B. 1999. Backyard Farming in the Tropics. CTA Pubblished.

Steel, R.G.D. and J.H. Torrie. 1980. Prinsip dan Prosedur Statistika. Suatu Pendekatan Biometrik, Edisi kedua. Diterjemahkan Oleh Sumantri. Gramedia. Jakarta.

Tillman, A.D., H. Hartadi, S . Reksohardiprodja.,P.Soeharto dan L. Soekamto. 1986. Ilmu Makanan Ternak Dasar. Gadjah Mada, University Press, Yogyakarta.

Xiccato, G. M.Bernardini, C.Castellini, A. Dalle Zotte, P.I. Queaque and A.Trocino.1999. Effect of postweaning feeding on the performance and energy balance of famale rabbits at different physiological states. Journal of Animal Science, Vol. 77 (2) : 416-426. 